\title{
Berat Badan Lahir Rendah sebagai Faktor Risiko Stunted pada Anak Usia Sekolah
}

Aulia Fakhrina, Neti Nurani, Rina Triasih

Departemen Ilmu Kesehatan Anak Fakultas Kedokteran, Kesehatan Masyarakat dan Keperawatan Universitas Gadjah Mada/ Rumah Sakit Umum Pusat Dr. Sardjito, Yogyakarta

Latar belakang. Stunted pada usia sekolah menyebabkan kemampuan kognitif rendah, fungsi fisik tidak optimal, dan produktivitas masa depan yang rendah.

Tujuan. Mengidentifikasi apakah berat badan lahir rendah (BBLR) merupakan faktor risiko stunted pada anak usia sekolah.

Metode. Kami melakukan penelitian kasus-kontrol dari bulan Mei - Desember 2016 yang melibatkan siswa sekolah dasar berusia 6-7 tahun yang dipilih secara cluster random sampling di lima kabupaten di Daerah Istimewa Yogyakarta. Stunted didefinisikan sebagai nilai $Z$ score untuk tinggi badan menurut usia <-2 standar deviasi berdasarkan kriteria WHO 2005. Data klinis dan demografi diperoleh menggunakan kuesioner yang diisi oleh orang tua.

Hasil. Kejadian stunted adalah 11,8\%. Riwayat BBLR (adjusted Odd Ratio (aOR) 3,38; IK 95\% 2,03 -5,63), jenis kelamin laki-laki (aOR 1,62; IK 95\% 1,160-2,27), usia kehamilan kurang bulan (aOR 4,23; IK 95\% 2,18-8,24), pola pemberian MPASI dini (aOR 1,65; IK 95\% 1,11-2,45) dan tinggal di daerah pedesaan (aOR 1,68; IK 95\% 1,01-2,62) merupakan faktor risiko terjadinya stunted pada usia sekolah. Stunted pada usia sekolah tidak berhubungan dengan pemberian ASI eksklusif dan tingkat pendidikan orang tua. Kesimpulan. Anak-anak yang lahir dengan BBLR berisiko mengalami stunted pada masa sekolah. Sari Pediatri 2020;22(1):18-23

Kata kunci: berat badan lahir rendah, stunted, anak usia sekolah, faktor risiko

\section{Low Birth Weight as Risk Factor of Stunted in School-Age Children}

Aulia Fakhrina, Neti Nurani, Rina Triasih

Background. Stunted at school-age period may lead to low cognitive capability, improper physical function, and low productivity in the future.

Objective. To identify whether low birth weight (LBW) is a risk factor of stunted among school-aged children.

Methods. We conducted a case-control study from May to December 2016, involving elementary school students aged 6-7 years, selected by cluster random sampling from five districts in Yogyakarta. Stunted was defined as z-score of height for age <-2 SD based on the WHO 2005 criteria. Clinical and demographic data were obtained using a questionnaire that was completed by the parents. Result. Stunted was identified in $11.8 \%$ of the study population. Children born with a history of LBW (adjusted OR/aOR of 3.38; 95\% CI: 2.03-5.63), male (aOR 1.62; 95\% CI: 1.16-2.27), premature (aOR 4.23; 95\% CI: 2.18-8.24), early complementary feeding (aOR 1.65; 95\% CI: 1.11-2.45), and living in rural areas (aOR 1.68; 95\% CI: 1.01-2.62) were more likely to be stunted at school-age period. Stunted at school-age period did not associate with exclusive breastfeeding and parent's education.

Conclusion. Children born with a history of LBW were more likely to be stunted during the school-age period. Sari Pediatri 2020;22(1):18-23

Keywords: low birth weight, stunted, school-age children, risk factor.

Alamat korespondensi: Rina Triasih. Departemen Ilmu Kesehatan Anak Fakultas Kedokteran, Kesehatan Masyarakat dan Keperawatan Universitas Gadjah Mada. Jl. Farmako Sekip Utara, Yogyakarta 55281. Email: rina_triasih@yahoo.com 
S ekitar 159 juta atau 23,8\% anak di dunia mengalami stunted. Riset Kesehatan Dasar (Riskesdas) tahun 2013 di Indonesia melaporkan prevalensi stunted secara nasional pada anak usia 5-12 tahun sebesar 30,7\% (12,3\% sangat pendek dan 18,4\% pendek). Prevalensi stunted terendah adalah di Daerah Istimewa Yogyakarta (14,9\%) dan tertinggi di Papua $(34,5 \%){ }^{1}$

Kekurangan gizi pada anak di periode emas (0-3 tahun), akan menyebabkan sel otak tidak tumbuh sempurna. Hal ini disebabkan $80-90 \%$ jumlah sel otak terbentuk semenjak masa dalam kandungan sampai usia dua tahun. Apabila gangguan tersebut terus berlangsung maka akan terjadi penurunan skor tes IQ (intelligence quotient) sebesar 10-13 poin. ${ }^{2}$ Stunted pada usia prasekolah dapat berlanjut menjadi stunted pada usia sekolah. Penelitian pada anak usia sekolah yang mengalami stunted menunjukkan hasil tes perhatian, memori kerja, belajar, dan kemampuan visuospasial yang kurang.

Faktor risiko terjadinya stunted pada anak secara garis besar dapat dikelompokkan menjadi lima, yaitu 1) infeksi dan nutrisi ibu, 2) ibu usia remaja dan jarak kelahiran yang pendek, 3) kelahiran kurang bulan dan gangguan pertumbuhan janin, 4) asupan makanan dan infeksi pada anak, dan 5) faktor lingkungan. ${ }^{3}$ Sebuah publikasi tentang analisis global faktor risiko stunted di 137 negara berkembang menunjukkan bahwa gangguan pertumbuhan janin merupakan faktor risiko stunted yang paling penting. ${ }^{3}$ Penelitian yang menggunakan data sekunder dari Riskesdas dan melibatkan 3024 anak usia 12-23 bulan di Indonesia melaporkan bahwa prediktor terkuat terjadinya stunted pada usia tersebut adalah berat badan lahir rendah (BBLR), jenis kelamin laki-laki, dan riwayat sakit saat masa neonatus. ${ }^{4}$ Pada anak usia sekolah di Teheran, Iran, BBLR, usia ibu dan tinggi ayah diidentifikasikan sebagai faktor risiko stunted. ${ }^{5}$

Beberapa penelitian menunjukkan bahwa anak dengan riwayat berat badan lahir rendah atau sangat rendah sering mengalami underweight dan stunted pada masa anak. ${ }^{6,7}$ Hubungan antara BBLR dengan stunted pada anak usia sekolah di Indonesia belum banyak yang dipublikasikan.

\section{Metode}

Penelitian cross sectional ini dilakukan di Provinsi Daerah Istimewa Yogyakarta (DIY) dari bulan Mei sampai bulan Desember 2016, yang merupakan bagian dari penelitian "Asma dan penyakit alergi pada anak usia sekolah", yang melibatkan anak usia 6-7 tahun (anak sekolah dasar/SD), di 5 kabupaten/kota di DIY, yaitu Kota Yogyakarta, Kabupaten Bantul, Sleman, Gunung Kidul dan Kulon Progo.

Penelitian ini mengikutsertakan anak usia 6-7 tahun, dengan kriteria inklusi: (1) Orang tua menyetujui sebagai peserta penelitian dengan menandatangani informed consent, (2) hadir pada saat penelitian. Kriteria eksklusi adalah menderita sakit berat atau penyakit kronis lainnya.

Dari 2106 anak usia 6-7 tahun yang diikutsertakan, 231 anak mengalami stunted. Seluruh anak stunted diikutsertakan sebagai kelompok kasus, sedangkan kelompok kontrol adalah 462 anak yang tidak stunted dipilih secara acak dengan tabel angka random menggunakan komputer, tanpa dilakukan matching.

Data penelitian dikumpulkan dengan menggunakan kuesioner. Pengisian kuesioner dilakukan oleh orang tua/wali dengan dipandu langsung oleh tim peneliti. Pemeriksaan fisik dilakukan oleh dokter dan asisten peneliti, meliputi pengukuran berat badan, tinggi badan, lingkar lengan atas, lingkar pinggang. Alat yang digunakan berupa timbangan berat badan injak digital, microtoise stature meter, dan pita lingkar lengan.

Kategori stunted adalah apabila $z$-score tinggi badam terhadap umur $(\mathrm{TB} / \mathrm{U})<-2 \mathrm{SD}$. Data lain yang dikumpulkan meliputi data berat badan lahir, jenis kelamin, usia kehamilan, pola pemberian ASI, pola pemberian MPASI, tingkat pendidikan orang tua, dan wilayah tempat tinggal.

Berat badan lahir rendah didefinisikan sebagai berat badan lahir < 2500 gram. Usia kehamilan kurang bulan merupakan persalinan yang berlangsung pada umur kehamilan <37 minggu. Definisi ASI eksklusif adalah memberikan hanya ASI saja untuk bayi sejak lahir sampai usia 6 bulan. Pemberian makanan pendamping ASI (MPASI)dini merupakan pola pemberian makanan pendamping kepada bayi sebelum berusia 6 bulan. Tingkat pendidikan orang tua yang rendah merupakan tingkat pendidikan tertinggi yang dicapai oleh orang tua SLTP ke bawah. Wilayah tempat tinggal di pedesaan merupakan daerah tempat tinggal anak berdasarkan Peraturan Badan Pusat Statistik no. 37 Tahun 2010 tentang klasifikasi perkotaan dan pedesaan di Indonesia.

Analisis data dilakukan dengan menggunakan program SPSS. Analisis bivariat dilakukan dengan 
chi square test untuk mengetahui variabel yang berhubungan dengan kejadian stunted (mempunyai nilai $\mathrm{p}<0,05)$. Analisis multivariat dilakukan untuk mengetahui variabel yang merupakan determinan terhadap kejadian stunted. Variabel-variabel hasil analisis bivariat yang mempunyai hubungan bermakna secara statistik kemudian dianalisis lebih lanjut dengan menggunakan regresi logistik.

Izin dari Komite Etik Penelitian Kedokteran Fakultas Kedokteran Universitas Gadjah Mada/ RSUP dr. Sardjito Yogyakarta telah didapatkan sebelum penelitian diselenggarakan, dengan nomor $\mathrm{KE} / \mathrm{FK} / 680 / \mathrm{EC} / 2016$. Orang tua/wali subjek yang bersedia mengikuti penelitian akan menandatangani informed consent.

\section{Hasil}

Dari 2350 anak umur 6-7 tahun di seluruh SD yang diikutsertakan, 2235 anak memenuhi kriteria penelitian. Kuesioner dapat dikumpulkan dari 2106 anak. Dari kuesioner tersebut, terdapat 147 kuesioner yang tidak lengkap datanya sehingga hanya ada 1959 kuesioner yang dapat dianalisis (Gambar 1).

Tabel 1. Karakteristik subjek penelitian

\begin{tabular}{lcc}
\hline Karakteristik & $\begin{array}{c}\text { Jumlah } \\
\mathrm{n}=693\end{array}$ & Persentase \\
\hline Asal wilayah & & \\
$\quad$ Kota Yogyakarta & 137 & 22,7 \\
Sleman & 157 & 19,8 \\
Kulon Progo & 145 & 20,9 \\
Bantul & 175 & 25,3 \\
$\quad$ Gunung Kidul & 79 & 11,4 \\
Area & & \\
Pedesaan & 111 & 16,0 \\
Perkotaan & 582 & 84,0 \\
Laki-laki & 340 & 49,1 \\
Prematur & 44 & 6,3 \\
Berat lahir & & \\
BBLR & 81 & 11,7 \\
$\quad$ BBLC & 612 & 88,3 \\
ASI eksklusif & 581 & 83,8 \\
MPASI dini & 149 & 21,5 \\
Pendidikan orang tua & & \\
Rendah & 224 & 32,3 \\
Tinggi & 469 & 67,7 \\
\hline
\end{tabular}

Dari 1959 anak tersebut, 231 (11,8\%) anak mengalami stunted. Rata-rata berat badan seluruh anak adalah 21,68 $( \pm 5,33) \mathrm{kg}$ dan rata-rata tinggi badan adalah $116,91( \pm 5,85) \mathrm{cm}$. Karakteristik subjek penelitian tertera pada Tabel 1. Proporsi laki-laki dan perempuan hampir sama (49,1\% laki laki dan 50,9\% perempuan).

Tabel 2 menunjukkan bahwa anak dengan riwayat berat badan lahir rendah, jenis kelamin laki-laki, usia kehamilan kurang bulan, pola pemberian MPASI dini dan wilayah tempat tinggal di pedesaan berisiko lebih tinggi untuk terjadinya stunted pada anak usia sekolah.

Analisis multivariat juga dilakukan dengan analisis stratifikasi Mantel-Haenszel untuk melakukan stratifikasi pada variabel luar yang berpotensi mengganggu. Dari Tabel 3 diketahui bahwa jenis kelamin laki-laki, pola pemberian ASI tidak eksklusif, pola pemberian MPASI dini, pendidikan orang tua yang rendah dan wilayah tempat tinggal di pedesaan merupakan confounding factor. Variabel dikatakan sebagai confounding factor jika mendistorsi effect dengan risk difference $>15 \%$.

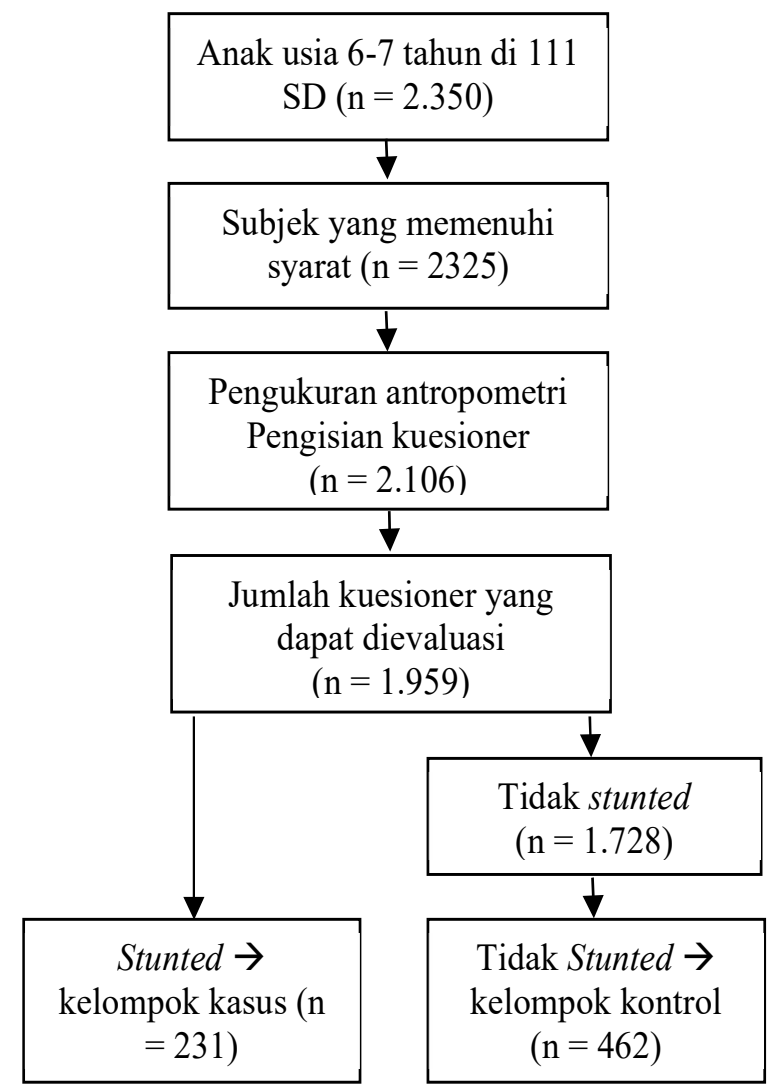

Gambar 1. Rekruitmen subjek penelitian 
Aulia Fakhrina dkk: Berat badan lahir rendah sebagai faktor risiko stunted pada anak usia sekolah

Tabel 2. Hasil analisis bivariat dan multivariat

\begin{tabular}{lcccc}
\hline \multirow{2}{*}{ Variabel } & \multicolumn{2}{c}{ Analisis bivariat } & \multicolumn{2}{c}{ Analisis multivariat } \\
\cline { 2 - 5 } & OR & $95 \%$ CI & Adjusted OR & $95 \%$ CI \\
\hline Berat badan lahir rendah & 4,08 & $2,52-6,62$ & 3,38 & $2,03-5,63$ \\
Laki-laki & 1,55 & $1,12-2,12$ & 1,62 & $1,16-2,27$ \\
Prematur & 3,85 & $2,04-7,26$ & 4,23 & $2,18-8,24$ \\
Tidak ASI eksklusif & 1,56 & $1,03-2,36$ & - & - \\
MP ASI dini & 2,03 & $1,40-2,95$ & 1,65 & $1,11-2,45$ \\
Tingkat pendidikan orang tua rendah & 1,48 & $1,06-2,06$ & 1,40 & $0,99-1,99$ \\
Pedesaan & 2,07 & $1,37-3,12$ & 1,68 & $1,01-2,62$ \\
\hline
\end{tabular}

Tabel 3. Hasil analisis stratifikasi

\begin{tabular}{lcccc}
\hline \multirow{2}{*}{ Variabel } & \multicolumn{2}{c}{ Analisis bivariat } & \multicolumn{2}{c}{ Analisis stratifikasi } \\
\cline { 2 - 5 } & OR & $95 \%$ CI & Adjusted MH-OR & $95 \%$ CI \\
\hline Laki-laki & 1,55 & $1,12-2,12$ & 4,21 & $2,58-6,87$ \\
Prematur & 3,85 & $2,04-7,26$ & 3,95 & $2,37-6,26$ \\
Tidak ASI eksklusi & 1,56 & $1,03-2,36$ & 3,91 & $2,41-6,37$ \\
MPASI dini & 2,03 & $1,40-2,95$ & 3,57 & $2,20-5,79$ \\
Tingkat pendidikan orang tua rendah & 1,48 & $1,06-2,06$ & 4,09 & $2,52-6,65$ \\
Pedesaan & 2,07 & $1,37-3,12$ & 3,51 & $2,15-5,76$ \\
\hline
\end{tabular}

\section{Pembahasan}

Prevalensi stunted pada anak umur 6-7 tahun di Provinsi DIY sebesar 11,8\%, tidak berbeda jauh dengan hasil Riset Kesehatan Dasar (Riskesdas) tahun 2013 yang menunjukkan prevalensi stunted di Provinsi DIY sebesar 14,9\% pada kelompok usia 5-12 tahun. ${ }^{1}$

Berat badan lahir rendah merupakan faktor risiko terjadinya stunted pada anak usia sekolah. Hal ini sejalan dengan penelitian Aryastami $\mathrm{dkk}^{4}$ yang menemukan bahwa BBLR merupakan faktor yang paling dominan menyebabkan stunted pada anak usia 12-23 bulan di Indonesia. Hasil ini juga sejalan dengan dengan penelitian Nasution ${ }^{8}$ di Kota Yogyakarta yang menemukan bahwa riwayat BBLR merupakan faktor risiko utama untuk stunted pada anak usia 6-24 bulan Penelitian di Bogota, Columbia, ${ }^{9}$ dilaporkan hal yang sama bahwa BBLR memiliki hubungan yang bermakna dengan kejadian stunted pada anak usia sekolah. Kondisi ini dapat terjadi karena pada bayi yang lahir dengan berat badan lahir rendah sejak dalam kandungan telah mengalami retardasi pertumbuhan interuterin. Selanjutnya, sampai usia setelah dilahirkan, yaitu mengalami pertumbuhan dan perkembangan yang lebih lambat dari bayi yang dilahirkan normal, dan sering gagal menyusul tingkat pertumbuhan yang seharusnya dia capai pada usianya setelah lahir. ${ }^{2}$

Anak yang lahir kurang bulan berisiko 3,84 kali lebih besar mengalami stunted dibanding anak yang lahir cukup bulan. Beberapa penelitian sebelumnya yang dilakukan pada anak usia antara $12-36$ bulan di Indonesia menunjukkan hasil yang sama. ${ }^{10,11}$ Pertumbuhan pada bayi kurang bulan mengalami keterlambatan karena usia kehamilan yang singkat dan adanya retardasi pertumbuhan linier di dalam kandungan. Bayi yang lahir cukup bulan apabila asupan gizinya kurang juga akan mengalami growth faltering. Hal ini akan bertambah berat jika ditambah dengan paparan penyakit infeksi. Sebaliknya, bayi prematur yang mengalami growth faltering jika diberikan dukungan asupan gizi yang adekuat maka pola pertumbuhan normal dapat terkejar ( catch up). ${ }^{12}$

Anak laki-laki 1,55 kali lebih berisiko mengalami stunted dibandingkan anak perempuan. Kondisi ini dapat terjadi karena jenis kelamin menentukan besarnya kebutuhan gizi bagi seseorang sehingga terdapat keterkaitan antara status gizi dan jenis kelamin. Anak laki-laki pada umumnya lebih aktif bermain di luar rumah daripada anak perempuan sehingga mereka menghabiskan energi yang lebih 
banyak sementara asupan eneginya terbatas, dan lebih mudah bersentuhan dengan lingkungan yang kotor. ${ }^{13}$ Hasil penelitian yang sama pada anak usia sekolah di Abeokuta, Nigeria, menemukan bahwa anak lakilaki lebih berisiko mengalami stunted dibandingkan dengan anak perempuan. ${ }^{13}$ Akan tetapi, penelitian di Kecamatan Lut Tawar Kabupaten Aceh Tengah memperlihatkan bahwa jenis kelamin laki-laki tidak meningkatkan risiko stunted pada siswa sekolah dasar di Kecamatan Lut Tawar, Kabupaten Aceh Tengah. ${ }^{14}$

Anak yang diberikan ASI eksklusif dan MPASI sesuai dengan kebutuhannya dapat mengurangi risiko terjadinya stunted. Hal ini karena pada usia 0-6 bulan, ibu yang memberikan ASI eksklusif dapat membentuk imunitas atau kekebalan tubuh sehingga dapat terhindar dari penyakit infeksi. Setelah itu, pada usia 6 bulan anak diberikan MPASI dalam jumlah dan frekuensi yang cukup sehingga anak terpenuhi kebutuhan zat gizinya yang dapat mengurangi risiko terjadinya stunted. ${ }^{15}$ Penundaan pemberian MPASI sampai usia 6 bulan dapat mengurangi risiko bayi terpapar dengan patogen yang ada dalam makanan, terutama di lingkungan dengan sanitasi yang buruk. Pemberian MPASI sangat diperlukan untuk menjaga pertumbuhan anak sekaligus memperkenalkan bayi dengan makanan keluarga. Selain untuk memenuhi kebutuhan bayi terhadap zat-zat gizi, pemberian MPASI merupakan salah satu proses pendidikan, bayi diajarkan untuk mengunyah, menelan makanan padat, dan membiasakan selera-selera baru. ${ }^{16}$ Pada penelitian ini ditunjukkan bahwa anak yang diberikan MPASI dini 2,03 kali lebih berisiko mengalami stunted dibanding anak yang diberikan MPASI sesuai usia. Pada anak usia 6-24 bulan pun dilaporkan bahwa pemberian MPASI dini meningkatkan risiko terjadinya stunted. ${ }^{17}$

Semakin tinggi tingkat pendidikan formal yang pernah ditempuh seseorang maka semakin mudah menyerap informasi baru. Orang tua dengan tingkat pengetahuan rendah cenderung menerima kebiasaan mengasuh serta memilih bahan makanan secara turun temurun dari orang tuanya atau orang disekitarnya yang kemungkinan memiliki tingkat pendidikan dan pengalaman yang kurang. Keadaan demikian yang dapat menjadi salah satu faktor yang dapat mengakibatkan terjadinya stunted pada anak. Tingkat pendidikan formal mempunyai hubungan dengan perubahan perilaku. Tingkat pendidikan yang tinggi akan mempermudah seseorang untuk menerima perubahan termasuk perubahan perilaku untuk tindakan protektif terhadap kejadian stunted lewat pemeliharaan sanitasi yang baik. ${ }^{18}$ Pada penelitian ini ditunjukkan bahwa anak dengan tingkat pendidikan orang tua yang rendah berisiko 1,48 kali lebih besar mengalami stunted dibanding anak dengan tingkat pendidikan orang tua yang tinggi, serupa dengan hasil penelitian di Nusa Tenggara Timur. ${ }^{19}$

Anak yang tinggal di wilayah pedesaan lebih berisiko mengalami stunted dibanding anak yang tinggal di wilayah perkotaan. Hasil penelitian di Nigeria dan penelitian lain di Indonesia juga melaporkan hasil serupa pada anak usia sekolah. ${ }^{20,21}$ Kejadian stunted pada anak usia sekolah dasar di wilayah pedesaan hampir dua kali dibandingkan wilayah perkotaan. Hal ini mungkin disebabkan oleh lebih sulitnya akses informasi dan fasilitas kesehatan pada masyarakat di wilayah pedesaan. Tingginya prevalensi stunted di wilayah pedesaan juga dapat terjadi akibat risiko infeksi saluran pencernaan yang lebih besar di wilayah pedesaan dibandingkan dengan perkotaan. ${ }^{20}$

Kelemahan penelitian ini adalah adanya kemungkinan recall bias pada data berat badan lahir, usia kehamilan, pola pemberian ASI eksklusif dan pola pemberian MPASI, karena data tersebut didapatkan secara retrospektif berdasarkan wawancara kepada orang tua/wali. Selain itu, beberapa kuesioner diisi oleh wali (kakek/nenek, paman, bibi, pengasuh) sehingga data tinggi badan orang tua, pola makan dan riwayat penyakit infeksi tidak bisa didapatkan. Kelemahan lain pada penelitian ini adalah tidak mengevaluasi lebih lanjut faktor-faktor penyebab lain seperti kelainan genetik, defisiensi hormon pertumbuhan, dan penyebab yang lainnya. Oleh karena itu data tersebut tidak dapat ditampilkan dan dianalisis dalam penelitian ini.

\section{Kesimpulan}

Prevalensi stunted pada anak usia sekolah (6-7 tahun) di Provinsi Daerah Istimewa Yogyakarta sebesar 11,8 $\%$. Berat badan lahir rendah, laki-laki, usia kehamilan kurang bulan, pola pemberian MPASI dini dan tempat tinggal di wilayah pedesaan merupakan faktor risiko terhadap terjadinya stunted pada anak usia sekolah.

\section{Daftar pustaka}

1. Kemenkes RI. Badan Penelitian dan Pengembangan Kesehatan Riset Kesehatan Dasar (Riskesdas). Jakarta: Kemenkes RI; 2013. 
Aulia Fakhrina dkk: Berat badan lahir rendah sebagai faktor risiko stunted pada anak usia sekolah

2. Caulfield LE, Richard SA, Rivera JA, dkk. Stunting, Wasting, and Micronutrient Deficiency Disorders. Dis Control Priorities Dev Ctries 2002;28:551-67.

3. Danaei G, Andrews KG, Sudfeld CR, dkk. Risk factors for childhood stunting in 137 developing countries: a comparative risk assessment analysis at global, regional, and country levels. PLoS Med 2016;13:1-18.

4. Aryastami NK, Shankar A, Kusumawardani N, dkk. Low birth weight was the most dominant predictor associated with stunting among children aged 12-23 months in Indonesia. BMC Nutr 2017;3:16.

5. Esfarjani F, Roustaee R, Mohammadi F, dkk. Determinants of stunting in school aged children of Tehran, Iran. Int J Prev Med 2013;4:173-9.

6. Ford GW, Doyle LW, Davis NM, Callanan C. Very low birth wieght and growth into adolescence. Arch Pediatr Adolesc Med 2000;154; 8: 778.

7. Hack M, Weissman B, Borawski-Clark E. Catch-up growth during childhood among very low birth weight children. Arch Pediatr Adolesc Med 1996; 150: 1121-1129.

8. Nasution D. Hubungan antara BBLR dengan kejadian stunting pada anak usia 6-24 bulan di Kota Yogyakarta. Universitas Gadjah Mada; 2014.

9. Dekker LH, Mora-Plazas M, Marín C, dkk. Stunting associated with poor socioeconomic and maternal nutrition status and respiratory morbidity in Colombian schoolchildren. Food Nutr Bull 2010;31:242-50.

10. Anugraheni HS, Kartasurya MI. Faktor risiko kejadian stunting pada anak usia 12-36 bulan di Kecamatan Pati, Kabupaten Pati. J Nutr Coll 2012;1:30-7.

11. Prawirohartono EP, Nurdiati DS, Hakimi M. Prognostic factors at birth for stunting at 24 months of age in rural Indonesia. Paediatr Indones 2016;56:48-56.

12. Meilyasari F, Isnawati M. Faktor risiko kejadian stunted pada balita usia 12 bulan di Desa Purwokerto, Kecamatan Patebon, Kabupaten Kendal. J Nutr Coll 2014;3:16-25.

13. Senbanjo IO, Oshikoya KA, Odusanya OO, dkk. Prevalence of and Risk factors for Stunting among School Children and Adolescents in Abeokuta, Southwest Nigeria 2011;29:364-70.

14. Aramico B, Sudargo T, Susilo J. Hubungan sosial ekonomi, pola asuh, pola makan dengan stunting pada siswa sekolah dasar di Kecamatan Lut Tawar, Kabupaten Aceh Tengah. J Gizi dan Diet Indones 2013;1:121-30.

15. Khasanah. Waktu pemberian makanan pendamping ASI (MP-ASI) berhubungan dengan kejadian stunting anak usia 6-23 bulan di Kecamatan Sedayu. J Gizi dan Diet Indones 2016;4:105-11.

16. Hijra, Muis SF, Irene MK. Inappropriate complementary feeding practice increases risk of stunting in children aged 12-24 months. Universa Medicana 2016;35:146-55.

17. Yulidasari F. MP-ASI sebagai faktor risiko kejadian stunting pada anak usia 6-24 bulan di Kota Yogyakarta. Universitas Gadjah Mada; 2013.

18. Semba RD, de Pee S, Sun K, dkk. Effect of parental formal education on risk of child stunting in Indonesia and Bangladesh: a cross-sectional study. Lancet (London, England) 2008;371:322-8.

19. Picauly I, Toy SM. Analisis determinan dan pengaruh stunted terhadap prestasi belajar anak sekolah di Kupang dan Sumba Timur, NTT. J Gizi dan Pangan 2013;8:55-62.

20. Adenuga W, Obembe T, Odebunmi K, dkk. Prevalence and determinants of stunting among primary school children in rural and urban ommunities in Obafemi Owode Local Government area, Southwestern Nigeria. Ann Ibadan Postgrad Med 2017;15:7-15.

21. Yasmin G. Faktor risiko stunting pada anak usia sekolah. Institut Pertanian Bogor; 2014. 